\title{
PENINGKATAN PENERAPAN METODE DISKUSI MELALUI KUNJUNGAN KELAS PADA GURU KELAS V SD BINAAN
}

\author{
Sutriyono,S.Pd.SD \\ Email: paktri00@gmail.com
}

\begin{abstract}
ABSTRAK
Metode mengajar merupakan ketrampilan yang harus dimiliki oleh seorang guru dalam mencapai tujuan pembelajaran. Oleh karena peranan metode mengajar sebagai alat untuk menciptakan proses belajar mengajar. Dengan metode diskusi dan resitasi ini diharapkan tumbuh berbagai kegiatan belajar siswa sehubungan dengan kegiatan mengajar guru. Dengan demikian tujuan dari penelitian ini adalah sebagai berikut: Pertama, mengetahui bagaimana implementasi metode diskusi dalam meningkatkan prestasi prestasi kinerja guru. Kedua, mengetahui apakah dengan adanya implementasi metode diskusi dapat meningkatkan prestasi belajar siswa. Penelitian ini menggunakan rancangan penelitian tindakan sekolah pengumpulan data menggunakan observasi dan catatan lapangan, dan teknik analisis dengan melakukan reduksi data, inferensi, tahap tindak lanjut dan pengambilan kesimpulan. Hasil penelitian menunjukkan metode diskusi adalah salah satu metode yang dapat digunakan untuk meningkatkan pemahaman guru terhadap suatu proses pembelajaran. Keaktifan siswa dalam proses diskusi dapat dirangsang melalui beberapa penghargaan seperti halnya memberikan nilai tambahan bagi siswa yang aktif dalam proses diskusi.
\end{abstract}

Kata kunci: metode diskusi, peningkatan kinerja guru

\section{PENDAHULUAN}

Untuk memperluas cara berfikir guru yang berhubungan dengan pendidikan,khususnya proses pembelajaran yang berhubungan dengan metode pembelajaran khususnya metode diskusi yang perlu diterapkan guru maka penulis perlu mengungkap teori-teori pendidikan dan pembelajaran oleh tokoh-tokoh pendidikan dan pembelajaran pada uraian-uraian pada isi Penelitian Tindakan Sekolah yang peneliti paparkan dan mewarnai isi dari laporan ini.

Tugas utama guru adalah bertanggung jawab membantu anak didik dalam hal belajar. Dalam proses belajar mengajar,gurulah yang menyampaikan pelajaran, memecahkan masalah-masalah yang terjadi dalam kelas, membuat evaluasi belajar siswa ,baik sebelum, sedang, maupun sesudah pelajaran berlangsung (Combs, 1984 : 11-13). Untuk memainkan peranan dan melaksanakan tugas-tugas itu,seorang guru diharapkan memiliki kemampuan profesional yang tinggi. Dalam hubungan ini makauntuk mengenal siswasiswanya dengan baik, guru perlu memiliki kemampuan untuk melakukan diagonis serta mengenal dengan baik cara-cara yang paling efektif untuk membantu siswa bertumbuh sesuai dengan potensinya masingmasing.

Di saat sekarang ini sering kita jumpai para siswa yang tidak punya kesiapan dalam menghadapi kegiatan belajar mengajar, terutama dalam hal materi pelajaran yang akan disampaikan, sehingga ketika di dalam kelas siswa tidak tahu materi yangakan dibahas,selain itu masalah alokasi waktu yang tidak mencukupi, sehingga menyebabkan interaksi belajar mengajar menjadi tidak efektif dan efisienserta tidak sesuai dengan tuntutan yang di harapkan oleh kurikulum. Oleh karena itu untuk mengatasi hal tersebut diperlukan suatu cara agar pelaksanaan belajar mengajar dapat terlaksana secara efektif yaitu dengan menerapkan atau menggunakan metode diskusi sebagai variasi dalam penyajian dalam proses pembelajaran baik itu tugas individu atau kelompok, rumah atau sekolah, merupakan salah satu metode dari beberapa metode yang ada sebagai langkah alternatif dalam rangka mengefektifkan dan mengefesienkan proses pemelajaran.

Dari 10 orang guru binaan berdasarkan hasil pengamatan/pemantauan terhadap penguasaan metode diskusi nilai yang diperoleh dengan jumlah 248 dengan rata-rata nilai 28,7 ,prosentase yang dicapai $42 \%$ dengan klasifikasi nilai $D$.

Berdasarkan uraian di atas, peneliti tertarik untuk mengadakan penelitian tentang "Penerapan Metode Diskusi dalam Meningkatkan Kemampuan Guru Kelas V SD Binaan Kecamatan Belitang Madang Raya Tahun 2017. Berdasarkan hasil dari kegiatan pengamatan pembelajaran ditemukan hal-hal 
Sebagaiberikut 1) Guru kurang kreatif dalam penggunaan metode pembelajaran, 2) Guru menerapan metode yang kurang relefan, 3) Guru kurang memahami metode pembelajaran,khususnya metode diskusi Sehubungan dengan fenomena di atas, maka ada dua permasalahan yang akan diajukan dalam penelitian ini, yaitu 1) Bagaimana implementasi metode diskusi dalam meningkatkan proses pembelajaran? 2) Apakah dengan adanya implementasi metode diskusi dapat meningkatkan kinerja guru?

Tujuan yang hendak dicapai dalam penelitian ini dapat dirumuskan sebagai berikut: 1) Mengetahui penerapan metode diskusi dalam meningkatkan proses pembelajaran di sekolah 2) Mengetahui apakah dengan adanya penerapan metode diskusi dapat meningkatkan kinerja guru.

Darihasil penelitian ini diharapkan dapat memberikan kontribusi dalam upaya untuk meningkatkan kemampuan proses pembelajaran,khususnya pada kegiatan proses pembelajaran guru kelas $\mathrm{V}$ SD binaan, adapun secara detail kegunaan tersebut di antaranya untuk 1) Untuk dijadikan bahan pertimbangan dan tambahan informasi dalam menentukan langkah-langkah penggunaan metode pembelajaran pada semua mata pelajaran di sekolah binaan. 2) Sebagai bahan pertimbangan guru untuk menerapkan metode yang tepat dalam proses pembelajaran yang sesuai dengan tujuan pembelajaran. 3) Dengan metode ini siswa diharapkan bisa menjadi bahan acuan dalam meningkatkan prestasi belajar siswa, juga dapat mempermudah siswa dalam menerima pelajaran. 4) Menambah wawasan dan pengetahuan lebih dalam tentang proses pembelajaran dengan berbagi variasi metode pembelajaran sehingga nanti dapat diaplikasikan secara langsung dalam proses pembelajaran.

\section{METODOLOGI PENELITIAN}

Dalam penelitian ini menggunakan rancngan penelitian tindakan sekolah (PTS) dimana dalam peneltian ini dilakukan mengikuti alur : refleksi awal, perencanaan tindakan, pengamatan, refleksi, dan peancanaan ulang. Penelitian tindakan sekolah ini difokuskan pada guru-guru SD sekolah binaan Kecamatan Belitang Madang Raya. Dengan mengadakan latihan-latihan pembuatan RPP dan latihan-latihan pembelajaran matei pemahaman bacaan dalam pembelajaran mata pelajaran,yang sesuai dengan jam pelajarn. Jadi materi materi pembelajaran harus benar-benar dikuasai oleh guru sehigga guru mampu melaksanakan tugasnya di dalam proses pembelajaran.

Penelitin ini dilaksanakan dengan cara pemantauan di kelas $\vee$ SDN sekolah binaan yang merupakan sekolah- sekolah dasar yang berada di Kecamatan Belitang Madang Raya dan merupakan sekolah yang cukup diminati oleh masyarakat untuk mengembangkan sumber daya manusia yang berkualitas.Sekolah sekolah menyediakan beberapa fasilitas pendukuan akadeik, diantaranya ruang kepala sekolah, ruang guru, ruang kelas yang berjumlah 6 kelas, dan ruang kantor yang dilengkapi laboratorium IPA, Pramuka,dan UKS, perpustakaan, fasilitas olahraga disediakan lapangan voli, dan sepak bola.

\section{Perencanaan Tindakan}

Dalam penelitian tindakan sekolah ini akan dipakai siklus yang dilakukan berulang-ulang dan berkelanjutan, sehingga diharapkan smakin lama semakin menunjang hasil yang akan dicapai.

Langkah-langkah kegiatan yang harus dipersiapkan dalam penelitian tindakan kelas ini adalah : 1) Pemantauan / observasi, 2) Konsultasi dengan guru pamong dan kepala sekolah, 3) Identiikasi permasalahan dengan kegiatan belajar mengajar di kelas $V$, 4) Merumuskan metode strategi yang sesuai dengan pembelajaran.

\section{Pengumuman Data}

Penelitian tindakan sekolah ini menggunakan beberapa cara untuk mengumpulkan data selama proses penelitian berlangsung diantaranya: 1) Metode Observasi, dimana peneliti mengadakan pemantauan yang dilakukan guru dalam pembelajaran. Yaitu penelitian yang dilakukan dengan cara pengamatan terhadap obyek (Sutrisno Hadi, 1986 : 136) dengan cara ini penelitian akan memperoleh data secara obyektif karena obyek tidak mengetahui bahwa dirinya sedang diteliti. 2) Pendekatan Partisipasi, dalampendekatan partisipatif ini ,peneliti langsung mengadakan kunjungan kelas dalam proses pembelajaran yang dilakukan guru.Pendekatan ini digunakan untuk lebih menjadi suasana dalam kegiatan belajar mengajar lebih hidup, 
sehingga peneliti terlibat secara langsung atau berpartisipasi dalam hal pengumpulan data yang diinginkan dan terkadang pula mengarahkan tindakan arahan yang mengarah kepada data diinginkan oleh peneliti.

\section{Skala Penelitian}

Penelitian disini bertujuan untuk mengetahui atau mengukur tingkat kreatifitas guru dalam kelas dan tingkat pemahaman guru terhadap metode diskusi yang sedang dikaji. Penilaian ini dilakukan pada kompetensi dasar yang dimiliki guru.

\section{HASIL DAN PEMBAHASAN Siklus Pertama}

\section{Perencanaan}

Untuk mengetahui pemahaman guru tentang konsep diskusi siswa, peneliti disini melaksanakan ujian pengetahuan konsep diskusi kemudian mengklasifikasikan menjadi sangat menguasai,menguasai belum menguasai dan tidak menguasai.

\section{Pelaksanaan}

Pada siklus ini dilaksanakan pada pertemuan pertama tepatnya pada minggu I dan II bulan Januari 2017, apa yang telah dilaksanakan berjalan sesuai dengan yang direncanakan yaitu memahami aktifitas guru dalam proses pembelajaran.

\section{Pengamatan}

Pada siklus pertama ini peneliti menfokuskan mengadakan pemantauan/pengamatan terhadap guru dalam proses pembelajaran di kelas V SD binaan di Kecamatan Bekitang Madang Raya.Khususnya memantau/mengamati penerapan metode yang digunakan guru dengan kesesuaiannya mata pelajaran yang diajarkan,

\section{Refleksi}

Dari hasil pengamatan/pemantauan peneliti disini ternyata penguasa an guru tentang penerapan metode pembelajaran dapat dikatakan relatif ren dah.Dimana masih banyak guru-guru pada SD sekolah binaan belum meng gunakan metode-metode yang sesuai dengan materi pembelajaran khususnya metode diskusi yang dapat merangsang tingkat berfikir siswa. Dari 10 orang guru binaan ini berdasarkan hasil pengamatan/pemantauan terhadap penguasaan metode diskusi nilai yang diperoleh dengan jumlah 248 dengan rata-rata nilai 28,7 , prosentase yang dicapai $42 \%$ dengan klasifikasi nilai D.

\section{Siklus kedua}

\section{Perencanaan}

Berdasarkan uraian pada siklus I,maka peneliti merencanakan mengadakan bimbingan dan pengarahan kepada guru-guru SD sekolah binaan melalui KKG,untuk menata/mengoreksi dan memperbaiki RPP yang sesuai dengan metode metode yang sesuai dengan materi pembelajaran yang mengarah pada pemakaian metode diskusi dan dalam penerapannya dalam proses pembelajaran.

\section{Pelaksanaan}

Pada siklus ini dilaksanakan pada minggu IV bulan Januari 2017 dan minggu I bulan Februari 2017 dan apa yang telah direncanakan pada minggu-minggu itu berjalan dengan lancar sesuai dengan apa yang telah dilaksanakannya.

\section{Pengamatan}

Dalam siklus ini peneliti dapat melakukan pengamatan/pemantauan secara langsung terhadap kegiatan belajar mengajar dimaana guru-guru sudah dapat melaksanakan/menerapkan metode yang sesuai dengan materi pembelajaran khususnya dengan penerapan metode diskusi yang sudah dibimbing dan diarahkan oleh peneliti.

\section{Refleksi}

Dalam siklus ke-2 ini,dari hasil pengamatan peneliti ternyata guru sudah mengalami peningkatan dalam pengelolaan proses pembelajarannya. Dimana guru sudah dapat merangsang anak dalam melakukan kegiatan diskusi,merangsang siswa untuk bertanya dan membuat suasana pembelajaran lebih hidup dari pada siklus pertama,walaupun masih terdapat kekurangan-kekurangan yang seharusnya tidak terjadi dan harus disempurnakan. Dari hasil pengamatan/pemantauan pada sikluske-2 ini mengalami peningkatan terhadap penguasaan metode diskusi dalam penerapan proses pembelajarannya dengan memperoleh jumlah 
nilai 459 ,rata-rata 45,9 dengan prosentase 67,5\% ,kwalifikasi yang diperoleh C. Dengan demikian pada siklus ke-2 ini,dibandingkan siklus yang ke-1 mengalami peningkatan 2,55\%

\section{Perencanaan}

\section{Siklus Ketiga}

Pada siklus ketiga ini,adalah proses kelanjutan dari pross pertama dan kedua. Menyempurnakan kekurangan-kekurangan yang dialami proses pertama dan kedua. peneliti merencanakan mengadakan bimbingan dan pengarahan lagi kepada guru-guru SD sekolah binaan melalui KKG,untuk menata/mengoreksi dan memperbaiki RPP yang sesuai dengan metode metode yang sesuai dengan materi pembelajaran yang mengarah pada pemakaian metode diskusi dan dalam penerapannya dalam proses pembelajaran.Terutama memperbaiki langkah-langkah pembelajarannya yang harus sesuai dengan metodenya,yaitu penerapan metode diskusi.

\section{Pelaksanaan}

Dalam siklus ketiga ini dilaksanakan pada minggu ketiga dan keempat dalam bulan Pebruari 2017.

\section{pengamatan}

Pada siklus ketiga ini peneliti mengadakan pengamatan /pemantauan langsung terhadap guru-guru SD sekolah binaan secara langsung, Dimana guru-guru di dalam melaksanakan proses pembelajaran sudah memahami dan bisa menerapkan metode diskusi sesuai yang diharapkan. Pelaksanaan kegiatan pembelajarannya sudah sesuai denga langkah-langkah pembelajarannya yang tertera di RPP. Proses pembelajaran sudah sangat hidup sekali.Pada siklus ini guru-guru dapat dikatakan bahwa sudah kreatif, aktif dan dapat merangsang siswa dalam berdiskusi.serta guru dapar membimbing siswa pada kegiatan diskusi yang sedang berlangsung.

\section{Refleksi}

Dalam siklus yang ketiga ini dari hasil pengamatan peneliti ternyata guru kreatif, aktif dalam melaksanakan metode diskusi dalam pembelajaran. Dengan demikian setelah siklus pertama sampai siklus ketiga dilakukan ternyata metode diskusi dapat dilaksanakan dengan mudah dan dapat mudah juga dalam mencapai tujuan pembelajaran yang diharapkan. Oleh karena itu, tidak mustahi peneliti memberi nilai tambahan pada guru-guru SD sekolah binaan dengan rincian jumlah nilai yang diperoleh 524 dengan ratarata nilai 52,4 prosentase yang diperoleh $7,70 \%$ sehingga kwalifikasi yang diperoleh $\mathrm{B}$. Pada siklus yang ke-3 ini mengalami peningkatan dibandingkan siklus ke-2 yaitu 0,95\%. Secara rinci hasil pencapaian nilai yang diperoleh dari siklus ke-1 sampai siklus ke-3 sebagai berikut:

Tabel :4.1 Nilai Penguasaan dan Penerapan Metode Diskusi Pembelajaran Guru-Guru Sekolah Binaan di Kecamatan Belitang Madang Raya

\begin{tabular}{|c|c|c|c|c|c|c|c|c|c|c|}
\hline \multirow{2}{*}{ No } & \multirow{2}{*}{ Nama Guru } & \multicolumn{3}{|c|}{ Siklus I } & \multicolumn{3}{|c|}{ Siklus II } & \multicolumn{3}{|c|}{ Siiklus III } \\
\hline & & $\mathrm{N}$ & $P$ & $\mathrm{~K}$ & $\mathrm{~N}$ & $\mathrm{P}$ & $\mathrm{K}$ & $\mathrm{N}$ & $P$ & $\mathrm{~K}$ \\
\hline 1 & Maryati,S.Pd.SD & 27 & 39 & $\mathrm{D}$ & 45 & 66 & $\mathrm{C}$ & 49 & 72 & $B$ \\
\hline 2 & Gunarwan,S.Pd.SD & 28 & 41 & $\mathrm{D}$ & 43 & 63 & $\mathrm{C}$ & 51 & 75 & $B$ \\
\hline 3 & Sujanto,S.Pd.SD & 26 & 38 & $\mathrm{D}$ & 44 & 64 & $\mathrm{C}$ & 60 & 88 & A \\
\hline 4 & Siti Nurjanah,S.Pd.I & 27 & 39 & $\mathrm{D}$ & 42 & 61 & $\mathrm{C}$ & 49 & 72 & $B$ \\
\hline 5 & Widyarko S,S.Pd.SD & 38 & 56 & $\mathrm{C}$ & 52 & 76 & $\mathrm{~B}$ & 62 & 88 & A \\
\hline 6 & Y.Indrayani,S.Pd.SD & 27 & 39 & $\mathrm{D}$ & 48 & 70 & $\mathrm{~B}$ & 49 & 72 & $\mathrm{~B}$ \\
\hline 7 & Sugeng,S.Pd.SD & 28 & 41 & $\mathrm{D}$ & 45 & 66 & $\mathrm{C}$ & 50 & 74 & $B$ \\
\hline 8 & Wiyono,S.Pd.SD & 27 & 39 & $\mathrm{D}$ & 45 & 66 & $\mathrm{C}$ & 48 & 71 & $B$ \\
\hline 9 & Ahmad,S.Pd.SD & 30 & 44 & $\mathrm{D}$ & 48 & 70 & $\mathrm{~B}$ & 49 & 72 & $B$ \\
\hline 10 & Sukiman,S.Pd.SD & 29 & 42 & $\mathrm{D}$ & 47 & 69 & $\mathrm{C}$ & 59 & 87 & $\mathrm{~A}$ \\
\hline & JUMLAH & 297 & 29 & $\mathrm{D}$ & 459 & 46 & $\mathrm{C}$ & 524 & 52 & $\mathrm{~B}$ \\
\hline
\end{tabular}

Keteterangan :N: Nilai yang diperoleh $\mathrm{P}$ :Prosentase $\mathrm{K}$ :Kwalifikasi

$$
D=\text { Kurang }, \quad C=\text { Sedang }, \quad B=\text { Baik }, \quad A=\text { Sangat Baik }
$$

Keterangan per siklus:

Siklus $1 \quad$ : 9 guru $(90 \%)$ memiliki aktifitas kurang

1 guru (25\%) memiliki aktifitas sedang

Siklus I I $\quad$ : 7 guru (70\%) memiliki aktifitas sedang 
Siklus III

3 guru (3\%) memiliki aktifitas baik

: 7 guru $(70 \%)$ memiliki aktifitas Baik

3.guru (3\%) memiliki aktifitas sangat baik

\section{Kesimpulan}

\section{PENUTUP}

Setelah peneliti mengadakan pengamatan terhadap penerapan metode diskusi dalam rangka meningkatkan kinerja guru yang aktif,kreatif dan menyenangkan untuk mencapai prestasi belajar siswa dengan menggunakan metode diskusi, maka disini dapat ditarik kesimpulan : 1) Metode diskusi adalah salah satu metode yang dapat digunakan untuk meningkatkan pemahaman guru dalam menyampaikan materi pembelajaran. 2) Kreatif,keaktifan dan pembelajaran yang menyenangkan,guru dalam proses diskusi dapat mencapai tujuan pembelajaran yang telah ditargetkan dapat tercapai. 3) Metode diskusi juga mengukur guru dari ranah kognitif afektifnya dan spikomotor. 4) Keberhasilan guru dalam proses pembelajaran yang menggunakan metode diskusi dapat dilihat dari hasil yang dicapai dan diraih siswa serta semangat dan perhatian siswa terhadap suatu mata pelajaran. 5) Kendala yang sering muncul di dalam proses diskusi adalah pertanyaan dan jawaban yang kurang mengena, maka guru dituntut dapat membimbing dan mengarahkan jalannya diskusi dalam proses pembelajaran.

\section{Saran}

Berdasarkan hasil dari penelitian dan pertimbangan berbagai keuntungan yang ada hendaknya penerapan pembelajaran dengan metode diskusi dapat diteruskan demi tercapainya tujuan pembelajaran.

Guru hendaknya terlebih dahulu membaca situasi dan kondisi lingkungan sekolah,situasi dan kondisi lingkungan siswa sebelum menerapkan suatu metode pembelajaran,sehingga guru dapat menerapkan metode yang tepat sesuai dengan materi pembelajaran yang akan disampaikan.

\section{UCAPAN TERIMAKASIH}

Terimakasih kepada Ketua STKIP Nurul Huda OKUTIMUR, Pembantu Ketua STKIP Nurul Huda OKU TIMUR, Ketua LPPM STKIP Nurul Huda OKUTIMUR, Anggota Jurnal Jemari STKIP Nurul Huda OKUT, Kepala Sekolah SD Binaan Di Kecamatan Belitang Madang Raya.

\section{DAFTAR PUSTAKA}

Ardana, Wayan. 1980. Beberapa Metode Statistik Untuk Keperluan Penelitian Pendidikan. Malang : swadaya. Arikunto, suharsimi. 1993. Manajemen Pengajaran Secara Manusiawi. Jakarta : Rineka Cipta.

-------. 1989. Penilaian program pendidikan. Proyek pengembangan LPTK Dekdikbud. Ditjen Dikti. 1998. Prosedur penelitian : suatu pendekatan praktek. Jakarta : Bina Aksara. 1989. Strategi Belajar Mengajar .jakarta : Bina Akksara. Abdul Ghafur. 1980. Desain intruksional.

Solo : Tiga serangkai. 1992. Dasar - Dasar Evaluasi Pendidikan. Jakarta : Bumi aksara. 1986. Dasar - Dasar Evaluasi Pendidikan. Jakarta : Bumi aksara.

Bahri saiful djamara. 1994. Prestasi Belajar dan Kompetensi Guru. Surabaya : UN.

Combs, Arthur W.1984. The profesional Education of teachersh. Allin and bacon, Inc, Boston

Darajat Zakiyah. 2000. Guru dan Anak Didikdalam Interaktif Edukatif. Jakarta : PT. Rineka Cipta.

Departemen pendidikan dan kebudayaan. 1993. Kurikulum SLTP 1994, landasan program pengajaran petunjukpelaksanaan kurikulum. Jakarta.

Djamarah, Syaiful Bahri. 1994. Guru dan Anak Didik dalam Interaktif Edukatif. fakultasTarbiah IAIN Antasari Banjarmasin.

Djamarah, Syaiful Bahri. 2002. Strategi Belajar Mengajar. Jakarta : PT Rineka Cipta. Hemalik,Oemar . 1992. Psikologi Belajar dan Mengajar. Sinar Baru.: Bandung. 